\title{
Pengaruh Pengangguran dan Kemiskinan Terhadap Pertumbuhan Ekonomi di Provinsi Gorontalo
}

Moh. Arif Novriansyah

Studi Pembangunan, Fakultas Ekonomi Universitas Gorontalo email: moharif_novriansyah@yahoo.com

\begin{abstract}
The province of Gorontalo as a resultant area of the North Sulawesi Province is certainly faced with unemployment and poverty problems, which is a common development problem faced by every region. the population condition of the area shows that the population in each regency in Gorontalo Province varies from one to another. From the condition of the population then needs to be analyzed about the effect of unemployment and poverty on economic growth in Gorontalo Province.

The purpose of this study is to determine the effect of unemployment and poverty on economic growth in Gorontalo Province. The results show that unemployment and poverty affect economic growth in Gorontalo Province. This is also in accordance with the results of calculations using a simple regression, where the level of significance of the whole one-sided correlation coefficient as measured by probability yields a figure of 0.019. Since the probability is less than 0.05, the correlation between the variables of unemployment and poverty (Variables X1 and X2) and economic growth (Variable $Y$ ) is significant.
\end{abstract}

Keywords: Unemployment, Poverty, Economic Growth

\section{PENDAHULUAN}

Pembangunan ekonomi adalah sebuah proses multidimensi yang melibatkan perubahan-perubahan besar dalam struktur sosial, sikap masyarakat, dan kelembagaan nasional, seperti halnya percepatan pertumbuhan ekonomi, pengurangan ketidakmerataan dan pemberantasan kemiskinan mutlak. Pertumbuhan ekonomi yang tinggi dan berkelanjutan merupakan kondisi utama suatu keharusan bagi kelangsungan pembangunan ekonomi dan peningkatan kesejahteraan. Karena jumlah penduduk bertambah setiap tahun yang dengan sendirinya kebutuhan konsumsi sehari-hari juga bertambah setiap tahun, maka dibutuhkan penambahan pendapatan setiap tahun (Tambunan, 2009). Selain dari sisi permintaan (konsumsi), dari sisi penawaran, pertumbuhan penduduk juga membutuhkan pertumbuhan kesempatan kerja (sumber pendapatan). Pertumbuhan ekonomi tanpa dibarengi dengan penambahan kesempatan kerja akan mengakibatkan ketimpangan dalam pembagian dari penambahan pendapatan tersebut (ceteris paribus), yang selanjutnya akan menciptakan 
suatu kondisi pertumbuhan ekonomi dengan peningkatan kemiskinan (Tulus T.H. Tambunan, 2009). Pemenuhan kebutuhan konsumsi dan kesempatan kerja itu sendiri hanya bisa dicapai dengan peningkatan output agregat (barang dan jasa) atau GDP yang terus-menerus. Dalam pemahaman ekonomi makro, pertumbuhan ekonomi adalah penambahan GDP, yang berarti peningkatan Pendapatan Nasional.

Pembangunan ekonomi sebuah negara dapat dilihat dari beberapa indikator perekonomian. Salah satu di antaranya adalah tingkat pengangguran. Berdasarkan tingkat pengangguran dapat dilihat kondisi suatu negara, apakah perekonomiannya berkembang atau lambat dan atau bahkan mengalami kemunduran. Selain itu dengan tingkat pengangguran, dapat dilihat pula ketimpangan atau kesenjangan distribusi pendapatan yang diterima suatu masyarakat negara tersebut. Pengangguran dapat terjadi sebagai akibat dari tingginya tingkat perubahan angkatan kerja yang tidak diimbangi dengan adanya lapangan pekerjaan yang cukup luas serta penyerapan tenaga kerja yang cenderung kecil persentasenya, Hal ini disebabkan rendahnya tingkat pertumbuhan penciptaan lapangan kerja untuk menampung tenaga kerja yang siap bekerja.

Berdasarkan data BPS menunjukkan jumlah penduduk indonesia yang mengalami kenaikan dari tahun-ketahun. Dimulai pada tahun 1980 sebesar 146.777.000 sampai pada tahun 2007 sebesar 224.904.000 jiwa (BPS, 1980 dan 2007). Kenaikan tersebut juga diikuti oleh kenaikan jumlah pengangguran, hal ini menunjukkan kenaikan jumlah penduduk tidak terserap ke lapangan pekerjaan sehingga jumlah pengangguran pun naik.

Peningkatan angkatan kerja baru yang lebih besar dibandingkan dengan lapangan kerja yang tersedia terus menunjukkan jurang (gap) yang terus membesar. Kondisi tersebut semakin membesar setelah krisis ekonomi. Dengan adanya krisis ekonomi tidak saja jurang antara peningkatan angkatan kerja baru dengan penyediaan lapangan kerja yang rendah terus makin dalam, tetapi juga terjadi pemutusan hubungan kerja (PHK). Hal ini menyebabkan tingkat pengangguran di Indonesia dari tahun ke tahun terus semakin tinggi.

Permasalahan pengangguran memang sangat kompleks untuk dibahas dan merupakan isu penting, karena dapat dikaitkan dengan beberapa indikator-indikator. Indikator-indikator ekonomi yang mempengaruhi tingkat pengangguran antara lain pertumbuhan ekonomi negara bersangkutan, tingkat inflasi, kemiskinan, serta besaran upah yang berlaku. Apabila di suatu negara pertumbuhan ekonominya mengalami kenaikan, diharapkan akan berpengaruh pada penurunan jumlah pengangguran, hal ini diikuti dengan tingkat upah. Jika tingkat upah naik akan berpengaruh pada penurunan jumlah pengangguran pula. Sedangkan tingkat inflasi yang tinggi akan berpengaruh pada kenaikan jumlah pengangguran (Sukirno, 2008).

Kemiskinan merupakan masalah yang dihadapi oleh semua negara di dunia, terutama negara sedang berkembang. Kemiskinan merupakan masalah kompleks yang dipengaruhi oleh berbagai faktor yang saling berkaitan, antara lain tingkat pendapatan masyarakat, pengangguran, kesehatan, pendidikan, akses terhadap barang dan jasa, lokasi, geografis, gender, dan lokasi lingkungan.

Kemiskinan tidak lagi dipahami hanya sebatas ketidakmampuan ekonomi, tetapi juga kegagalan memenuhi hak-hak dasar dan perbedaan 
perlakuan bagi seseorang atau sekelompok orang dalam menjalani kehidupan secara bermartabat. Hak-hak dasar yang diakui secara umum meliputi terpenuhinya kebutuhan pangan, kesehatan, pendidikan, pekerjaan, perumahan, air bersih, pertanahan, sumber daya alam, lingkungan hidup, rasa aman dari perlakuan atau ancaman tindak kekerasan, dan hak berpartisipasi dalam kehidupan sosial politik. Banyak dampak negatif yang disebabkan oleh kemiskinan, selain timbulnya banyak masalah-masalah sosial, kemiskinan juga dapat mempengaruhi pembangunan ekonomi suatu negara. Kemiskinan yang tinggi akan menyebabkan biaya yang harus dikeluarkan untuk melakukan pembangunan ekonomi menjadi lebih besar, sehingga secara tidak langsung akan menghambat pembangunan ekonomi.

Kemiskinan merupakan penyakit yang muncul saat masyarakat selalu mempunyai kekurangan secara material maupun non material seperti kurang makan, kurang gizi, kurang pendidikan, kurang akses informasi, dan kekurangan-kekurangan lainnya yang menggambarkan kemiskinan. Faktor lain yang sangat nyata tentang kemiskinan terutama di kota-kota besar Indonesia, dapat dilihat dari banyaknya warga masyarakat yang kekurangan makan dan minum, tidak memiliki tempat tinggal yang layak, bahkan digusur dari pemukimannya, ribuan pekerja berunjuk rasa memprotes ancaman pemutusan hubungan kerja (PHK), sikap dan perlakuan sewenang-wenang terhadap tenaga kerja wanita di luar negeri. Kemudian ketidakadilan sosial ekonomi, selain oleh beragam alasan juga disebabkan oleh praktek korupsi, kolusi, dan nepotisme yang tidak sehat.

Pada akhirnya pengangguran da kemiskinan akan mempengaruhi pertumbuhan ekonomi suatu negara atau daerah, hal ini jelas mengingat pertumbuhan ekonomi merupakan salah satu indikator yang amat penting dalam menilai kinerja suatu perekonomian, terutama untuk melakukan analisis tentang hasil pembangunan ekonomi yang telah dilaksanakan suatu negara atau suatu daerah. Ekonomi dikatakan mengalami pertumbuhan apabila produksi barang dan jasa meningkat dari tahun sebelumnya. Pertumbuhan ekonomi menunjukkan sejauh mana aktivitas perekonomian dapat menghasilkan tambahan pendapatan atau kesejahteraan masyarakat pada periode tertentu. Pertumbuhan ekonomi suatu Negara atau suatu wilayah yang terus menunjukkan peningkatan menggambarkan bahwa perekonomian negara atau wilayah tersebut berkembang dengan baik.

Provinsi Gorontalo sebagai daerah hasil pekeran dari Provinsi Sulawesi Utara tentunya diperhadapkan dengan masalah penganguran dan kemiskinan, yang merupakan masalah pembangunan yang umum dihadapi oleh setiap daerah. kondisi kependudukan daerah menunjukan bahwa jumlah penduduk di tiap tiap Kabupaten yang ada di Provinsi Gorontalo bervariasi antara satu dengan lainnya. Dari kondisi jumlah penduduk tersebut kemudian perlu dianalisis tentang pengaruh pengangguran dan kemiskinan terhadap pertumbuhan ekonomi di Provinsi Gorontalo.

Bertitik tolak dari uraian di atas maka perlu dikaji dan diteliti secara mendalam tentang "Pengaruh Pengangguran dan Kemiskinan Terhadap Pertumbuhan Ekonomi Di Provinsi Gorontalo". 


\section{TINJAUAN PUSTAKA}

2.1 Konsep Pertumbuhan Ekonomi

Adapun menurut Shumpeter, dalam Putong (2010) bahwa pertumbuhan ekonomi adalah pertambahan output (pendapatan nasional) yang disebabkan oleh pertambahan alami dari tingkat pertambahan penduduk dan tingkat tabungan. Sedangkan menurut beberapa pakar ekonomi pembangunan, pertumbuhan ekonomi adalah merupakan istilah bagi negara yang telah maju untuk menyebut keberhasilan pembangunannya, sementara itu untuk negara yang sedang berkembang digunakan istilah pembangunan ekonomi.

Murni (2009) kembali menjelaskan bahwa faktor yang menunjang pertumbuhan ekonomi antara lain : sumber kekayaan alam (R), sumber daya manusia (L), sumber daya modal (K), teknologi dan inovasi (T), keahlian berupa manajemen dan kewiraswataan (S), dan informasi (Inf). Semua faktor ini sangat mempengaruhi pertumbuhan GNP suatu negara. Hubungan antara produk nasional dan faktor-faktor pertumbuhan ekonomi tersebut dapat dinyatakan dalam bentuk fungsi :

$$
Q=\mathbf{f}(\mathbf{R}, \mathbf{L}, \mathbf{K}, \mathbf{T}, \mathbf{S}, \mathbf{I n f})
$$

Dimana :

$\begin{array}{ll}\mathrm{Q} & =\text { Output Nasional } \\ \mathrm{R} & =\text { Sumber Daya Alam } \\ \mathrm{L} & =\text { Sumber Daya Manusia } \\ \mathrm{K} & =\text { Barang Modal } \\ \mathrm{T} & =\text { Teknologi dan Inovasi } \\ \mathrm{S} & =\text { Keahlian } \\ \mathrm{Inf} & =\text { Informasi }\end{array}$

Terdapat banyak rumus yang dipergunakan untuk menghitung pertumbuhan ekonomi, akan tetapi pada umumnya yang paling sering dipergunakan adalah dengan metode hitung atau metode aritmatik, yaitu menghitung pertambahan PDB atau GNP (perkapita) dari tahun ke tahun. Rumusnya adalah sebagai berikut :

$$
G g n p=\frac{G N P n-G N P n-1}{G N P n-1} X 100 \%
$$

Dimana Ggnp adalah tingkat pertumbuhan ekonomi, GNPn adalah GNP tahun berikutnya, dan GNPn-1 adalah GNP tahun lalu. Adapun kebaikan dengan mengunakan rumus ini adalah kita dapat menentukan besarnya pertumbuhan tiap tahunnya, sedangkan kelemahannya adalah cara ini tidak mudah menentukan berapa besarnya pertumbuhan rata-rata tiap tahunnya bila data yang ada rentangnya terlalu jauh.

\subsection{Konsep Pengangguran}

Murni (2009 : Hal 191) menjelaskan bahwa istilah pengangguran selalu dikaitkan dengan angkatan kerja (labor force). Angkatan kerja adalah bagian dari penduduk;

Berusia antara 15 sampai dengan 65 tahun

- Mempunyai kemamuan dan kemampuan untuk bekerja 


\section{- $\quad$ Sedang mencari pekerjaan}

2.3 Konsep Kemiskinan

Menurut Lembaga Penelitian SMERU (2001) orang miskin memandang bahwa kemiskinan adalah suatu keadaan ketika seseorang kehilangan harga diri, terbentur pada ketergantungan, terpaksa menerima perlakuan kasar dan hinaan, serta tidak dipedulikan ketika sedang mencari pertolongan. SMERU juga mengungkapkan pengertian lain kemiskinan yakni sebagai ketidakmampuan seseorang dalam memenuhi kebutuhan konsumsi dasar dan meningkatkan kualitas hidupnya. Kemiskinan timbul karena adanya ketimpangan dalam kepemilikan alat produksi, kemiskinan terkait pula dengan sikap, budaya hidup, dan lingkungan tertentu dalam suatu masyarakat. Kemiskinan juga diartikan sebagai ketidakberdayaan sekelompok masyarakat dibawah suatu sistem pemerintahan yang menyebabkan mereka berada pada posisi yang sangat lemah dan tereksploitasi. Tidak jauh berbeda Peter Townsend (Roberd Gordon University) menyatakan bahwa kemiskinan adalah ketiadaan atau kekurangan makanan, kenyamanan, standard pelayanan dan kegiatan yang dibutuhkan oleh masyarakat.

\section{Gambar 2. Lingkaran Setan Kemiskinan Versi Nurkse}

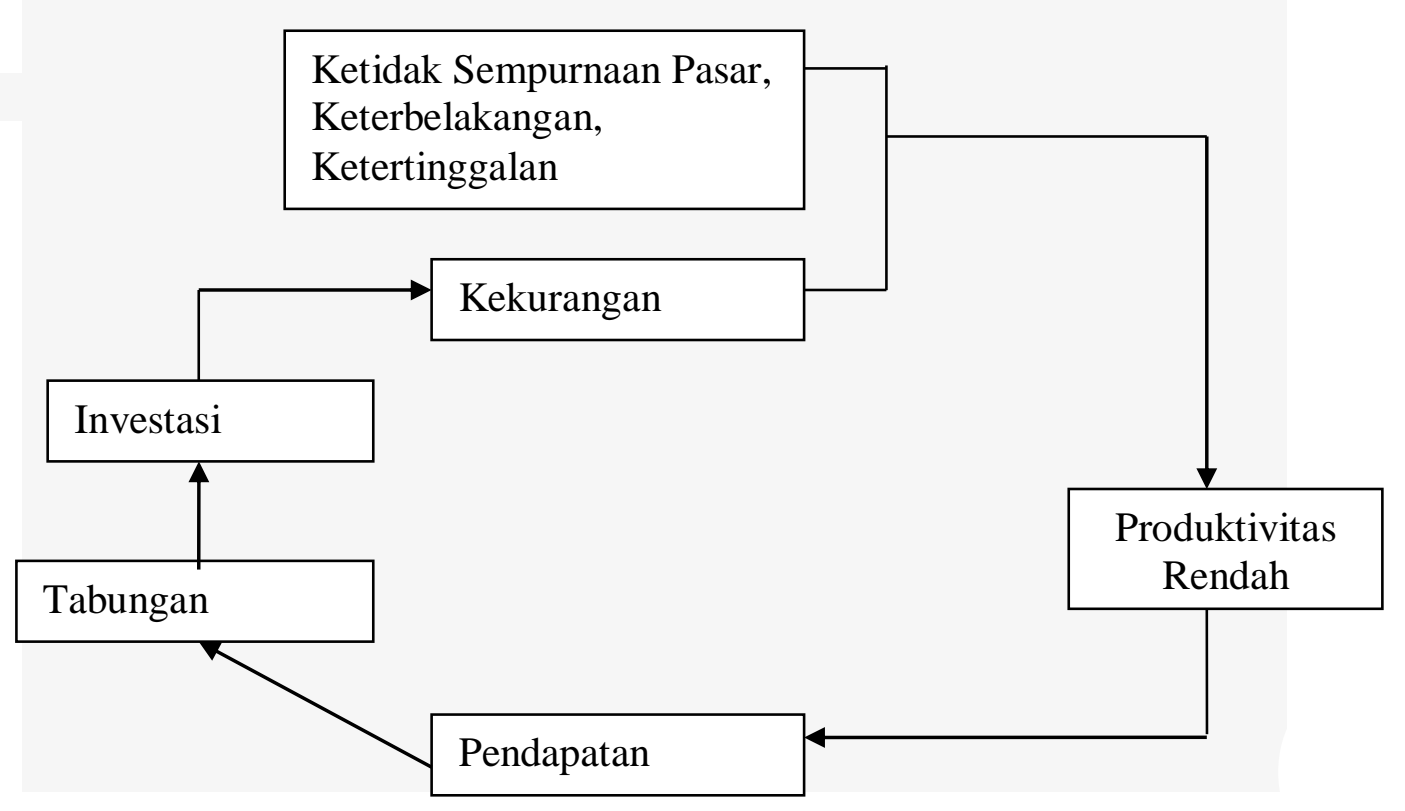

3. METODE PENELITIAN

\subsection{Definisi Operasional Variabel}

1. Pertumbuhan Ekonomi adalah suatu kondisi dimana terjadinya perkembangan GDP yang mencerminkan adanya pertumbuhan output perkapita dan meningkatnya standar hidup masyarakat yang terjadi di Provinsi Gorontalo, yang dihitung setiap tahunnya dalam persen.

2. Pengangguran di provinsi Gorontalo diukur melalui tingkat pengangguran Provinsi Gorontalo. Tingkat pengangguran dihitung berdasarkan perbandingan antara jumlah orang yang menganggur dan jumlah angkatan kerja, yang dihitung setiap tahunnya dalam persen. 
3. Kemiskinan di provinsi Gorontalo diukur melalui tingkat kemiskinan Provinsi Gorontalo. Tingkat kemiskinan (Head Count Index), yang merupakan angka perbandingan penduduk yang berada dibawah garis kemiskinan dengan jumlah penduduk secara keseluruhan, yang dihitung setiap tahunnya dalam persen.

\subsection{Jenis dan Sumber Data}

1. Jenis Data

Dalam penelitian ini, ada dua jenis data yang dikumpulkan oleh peneliti guna menguji hipotesis yang diajukan, yaitu:

a) Data kuantitatif yang berupa berbagai jenis data dalam bentuk angkaangka.

b) Data kualitatif yaitu data yang dapat mendukung data kuantitatif dalam pemecahan kasus yang berupa penjelasan secara deskriptif terhadap berbagai faktor yang mempengaruhi dalam pemecahan kasus seperti informasi - informasi yang berkaitan dengan masalah

2. Sumber data

a. Data Primer

Yaitu data yang diperoleh langsung dari obyek penelitian baik melalui pengamatan maupun wawancara (interview)

b. Data Sekunder

Yaitu data yang telah ada pada obyek penelitian atau data hasil penelitian yang sudah pernah dilakukan sebelumnya, dimana data tersebut bersumber dari dokumen organisasi tersebut atau institusi lainnya, yang dianggap berkaitan atau relevan dengan masalah yang di bahas

\subsection{Metode Pengumpulan Data}

Dalam penelitian ini peneliti akan menggunakan metode pengumpulan data sebagaimana yang dikemukakan oleh Indriantoro dan Supomo (2002, hal.152) yaitu Penelitian Kepustakaan (Library Research) yaitu penelitian yang dilakukan dengan mengutip beberapa literatur-literatur seperti : buku-buku, majalah, brosur dan karangan lainnya yang erat hubungannya dengan permasalahan yang diteliti. Dengan kata lain penulis mengumpulkan data yang sifatnya dokumen sehubungan dengan objek yang akan diteliti.

\subsection{Metode Analisis}

1. Metode Kualitatif

Dalam hal ini akan di paparkan berdasarkan analisis kondisi obyektif dan temuan-temuan yang dihubungkan dengan teori-teori ilmiah, sehingga diperoleh gambaran secara sistematis, faktual dan aktual serta solusisolusi terhadap pemecahannya.

2. Metode analisis Kuantitatif

Model analisis kuantitatif digunakan untuk menganalisa pengaruh pengangguran dan kemiskinan terhadap pertumbuhan ekonomi di Provinsi Gorontalo dengan metode analisis regresi berganda. Adapun formulasi dari analisis regresi linier berganda adalah sebagai berikut : (Sumarsono, 2004, hal 257)

$$
\mathbf{Y}=\boldsymbol{\beta}_{0}+\boldsymbol{\beta}_{1} \mathbf{X}_{1}+\boldsymbol{\beta}_{2} \mathbf{X}_{2}
$$


Dimana :

$\mathrm{X}_{1}=$ Tingkat Pengangguran Provinsi Gorontalo $(\%)$

$\mathrm{X}_{2}=$ Tingkat Kemiskinan Provinsi Gorontalo (\%)

$\mathrm{Y}=$ Pertumbuhan Ekonomi Provinsi Gorontalo (\%)

$\boldsymbol{\beta} 0=$ intersep, konstanta yang merupakan rata - rata nilai $\mathrm{Y}$ apabila variabel lain dianggap konstan

Untuk memudahkan proses perhitungan, uji hipotesis akan digunakan

bantuan Komputer dengan menggunakan fasilitas SPSS (Statistical Program Service Solution) versi 16.0.

\section{HASIL PENELITIAN DAN PEMBAHASAN}

\subsection{Deskripsi Pertumbuhan Ekonomi Provinsi Gorontalo}

Pertumbuhan ekonomi mengkaitkan dan menghitung antara tingkat pendapatan nasional dari satu period ke periode berikutnya. Angka pertumbuhan ekonomi umumnya dalam bentuk prosentasi dan bernilai positif, tapi juga mengkin saja bernilai negatif (misalkan saja pertumbuhan ekonomi Indonesia tahun 1998 minus sekitar 4\% - 6\%). Negatifnya pertumbuhan ekonomi tentu saja disebabkan adanya penurunan yang lebih besar dari pendapatan nasional tahun berikutnya dibandingkan tahun sebelumnya. Jika dalam menghitung pertumbuhan ekonomi nasional, yang diperlukan adalah data PDB, maka untuk menghitung pertumbuhan ekonomi suatu wilayah atau daerah diperlukan data PDRB/GDP.

Dengan PDRB mencapai 20.781.308,3 (juta rupiah) tahun 2010-2014, maka tingkat pertumbuhan ekonomi Provinsi Gorontalo mengalami kenaikan dari tahun ke tahun, berikut ini digambarkan kondisi pertumbuhan ekonomi Provinsi Gorontalo sebagai berikut :

Tabel 4.1.1 Pertumbuhan Ekonomi Provinsi Gorontalo Tahun 2006-2014

\begin{tabular}{|c|c|c|}
\hline No & Tahun & Pertumbuhan Ekonomi (\%) \\
\hline 1 & 2006 & 7.30 \\
\hline 2 & 2007 & 7.51 \\
\hline 3 & 2008 & 7.76 \\
\hline 4 & 2009 & 7.54 \\
\hline 5 & 2010 & 7.63 \\
\hline 6 & 2011 & 7.71 \\
\hline 7 & 2012 & 7.91 \\
\hline 8 & 2013 & 7.68 \\
\hline 9 & 2014 & 7.29 \\
\hline
\end{tabular}

Dari tabel diatas dapat dilihat bahwa pertumbuhan ekonomi di Provinsi Gorontalo mengalami peningkatan selama tahun 2006-2014, dimana pada tahun 2006 jumlah pertumbuhan ekonomi Gorontalo adalah sebesar 7,30\% 
kemudian naik menjadi menjadi $7.51 \%$ tahun 2007 dan $7.76 \%$ tahun 2008 . Tahun 2009 pertumbuhan ekonomi Gorontalo turun dari tahun sebelumya yaitu menjadi $7.54 \%$ namun kemudian naik lagi menjadi $7.63 \%$ tahun 2010 ; $7.71 \%$ tahun 2011, 7,91 tahun 2012 ; kemudian turun menjadi 7,68\% tahun 2012 dan terakhir tahun 2013 berada pada angka 7.29\%.

\subsection{Deskripsi Pengangguran Provinsi Gorontalo}

Adapun tingkat pengangguran di Provinsi Gorontalo dapat dilihat pada tabel berikut ini :

Tabel 4.2.1. Tingkat Pengangguran Provinsi Gorontalo Tahun 2006-2014

\begin{tabular}{|c|c|c|}
\hline No & Tahun & Tingkat Pengangguran Terbuka (\%) \\
\hline 1 & 2006 & 7.62 \\
\hline 2 & 2007 & 7.16 \\
\hline 3 & 2008 & 5.65 \\
\hline 4 & 2009 & 5.89 \\
\hline 5 & 2010 & 5.16 \\
\hline 6 & 2011 & 6.68 \\
\hline 7 & 2012 & 4.44 \\
\hline 8 & 2013 & 4.15 \\
\hline 9 & 2014 & 4.18 \\
\hline
\end{tabular}

Sumber : BPS Kabupaten Gorontalo, 2015

Dari tabel diatas dapat dilihat bahwa tingkat pengangguran terbuka di Provinsi Gorontalo cukup berfluktuasi, dimana pada tahun 2006 tingkat pengangguran terbuka Provinsi Gorotalo sebesar $7.62 \%$ kemudian mengalami penurunan tahun 2007 dan 2008 yaitu 7.62\% dan 5.65\%. Pada tahun 2009 naik lagi menjadi 5.89\% dan kembali turun pada tahun 2010 menjadi 5.16\% dan naik lagi tahun 2011 menjadi $6.68 \%$, dan kembali turun pada tahun 2012 yaitu 4.44\% ; dan tahun 2013 menjadi 4.15\% selanjutnya pada tahun 2014 naik lagi menjadi $4.18 \%$.

\subsection{Deskripsi Kemiskinan Provinsi Gorontalo}

Penduduk miskin Gorontalo umumnya adalah penduduk yang bekerja di sektor pertanian, yang menyerap tenaga kerja paling banyak di Gorontalo. Baik Petani maupun Nelayan memiliki modal terbatas dan rata-rata mereka adalah tenaga kerja musiman. Di beberapa daerah pelosok Gorontalo, nelayan masih terjebak dengan praktek ijon sehingga memperparah kondisi pendapatan mereka, dan pada akhirnya akses terhadap pendidikan dan kesehatan mereka terbatas.

Selanjutnya digambarkan persentase penduduk miskin / tingkat kemiskian Provinsi Gorontalo pada tabel dibawah ini : 
Tabel 4.3.1 Tingkat Kemiskinan

Provinsi Gorontalo Tahun 2006-2014

\begin{tabular}{|c|c|c|}
\hline No & Tahun & $\begin{array}{c}\text { Tingkat Kemiskinan } \\
(\mathbf{\%})\end{array}$ \\
\hline 1 & 2006 & 29.13 \\
\hline 2 & 2007 & 27.35 \\
\hline 3 & 2008 & 24.88 \\
\hline 4 & 2009 & 25.01 \\
\hline 5 & 2010 & 23.19 \\
\hline 6 & 2011 & 18.75 \\
\hline 7 & 2012 & 17.33 \\
\hline 8 & 2013 & 17.51 \\
\hline 9 & 2014 & 17.44 \\
\hline
\end{tabular}

Sumber : BPS Provinsi Gorontalo, 2016

Dari tabel diatas dapat dilihat bahwa tingkat kemiskinan di Provinsi Gorontalo cukup berfluktuasi, dimana pada tahun 2006 tingkat kemiskinan Provinsi Gorotalo sebesar 29.13\% kemudian mengalami penurunan tahun 2007 dan 2008 yaitu 27.35\% dan 24.88\%. Pada tahun 2009 naik lagi menjadi $25.01 \%$ dan kembali turun pada tahun 2010, 2011, dan 2012 yaitu $23.19 \%$; $18.75 \%$ dan $17.33 \%$. naik lagi pada tahun 2013 menjadi $17.51 \%$ dan turun pada tahun 2014 menjadi $17.44 \%$.

Selanjutnya untuk melihat garis kemiskinan di Provinsi Gorontalo dapat dilihat pada tabel berikut ini :

Tabel 4.3.2 Garis Kemiskinan

Provinsi Gorontalo Tahun 2006-2014

\begin{tabular}{|c|c|c|}
\hline No & Tahun & $\begin{array}{c}\text { Garis Kemiskinan } \\
\text { (Rupiah/Kapita/Bulan) }\end{array}$ \\
\hline 1 & 2006 & 130.668 \\
\hline 2 & 2007 & 138.181 \\
\hline 3 & 2008 & 147.154 \\
\hline 4 & 2009 & 162.189 \\
\hline 5 & 2010 & 171.371 \\
\hline 6 & 2011 & 187.215 \\
\hline 7 & 2012 & 203.907 \\
\hline 8 & 2013 & 221.457 \\
\hline 9 & 2014 & 243.547 \\
\hline
\end{tabular}

Sumber : BPS Provinsi Gorontalo, 2016

Dari tabel diatas dapat dilihat bahwa garis kemiskinan Provinsi Gorontalo mengalami peningkatan dari tahun 2006-2014, dimana pada tahun 2006 garis kemiskinan Gorontalo adalah ebesar Rp. 130.668,- kemudian terus mengalami kenaikan hingga tahun 2014 menjadi sebesar Rp. 243.547,-- Hal ini berarti pada tahun 2014 seorang penduduk Gorontalo dikatakan miskin apabila pengeluaran/pendapatannya kurang dari Rp.243.547 per bulan atau 
Rp.8.118 per hari. Apabila seorang kepala rumahtangga (KRT) memiliki dua anak dan satu istri, berarti pendapatan minimal agar ia dapat memenuhi kebutuhan dasar untuk dia dan keluarganya adalah Rp. 974.160 per bulan atau Rp.32.472 per hari.

\subsection{Analisis Pengangguran Dan Kemiskinan Terhadap Pertumbuhan Ekonomi di Provinsi Gorontalo}

Permasalahan pengangguran memang sangat kompleks untuk dibahas dan merupakan isu penting, karena dapat dikaitkan dengan beberapa indikator-indikator. Indikator-indikator ekonomi yang mempengaruhi tingkat pengangguran antara lain pertumbuhan ekonomi negara bersangkutan, tingkat inflasi, kemiskinan, serta besaran upah yang berlaku. Apabila di suatu negara pertumbuhan ekonominya mengalami kenaikan, diharapkan akan berpengaruh pada penurunan jumlah pengangguran, hal ini diikuti dengan tingkat upah. Jika tingkat upah naik akan berpengaruh pada penurunan jumlah pengangguran pula. Pada akhirnya penurunan tingkat pengangguran diharapkan akan dapat mengurangi tingkat kemiskinan.

Berikut ini dijelaskan tingkat pengangguran dan tingkat kemiskinan serta Pertumbuhan Ekonomi di Provinsi Gorontalo sebagaimana terdapat pada tabel dibawah ini :

Tabel 4.4.1 Tingkat Pengangguran Terbuka, Tingkat Kemiskinan dan Pertumbuhan Ekonomi Provinsi Gorontalo Tahun 2006-2014

\begin{tabular}{|c|c|c|c|c|}
\hline No & Tahun & $\begin{array}{c}\text { Tingkat } \\
\text { Pengangguran } \\
\text { Terbuka } \\
\text { (\%) }\end{array}$ & $\begin{array}{c}\text { Tingkat } \\
\text { Kemiskinan } \\
\text { (\%) }\end{array}$ & $\begin{array}{c}\text { Pertumbuhan } \\
\text { Ekonomi } \\
\text { (\%) }\end{array}$ \\
\hline 1 & 2006 & 7.62 & 29.13 & 7.30 \\
\hline 2 & 2007 & 7.16 & 27.35 & 7.51 \\
\hline 3 & 2008 & 5.65 & 24.88 & 7.76 \\
\hline 4 & 2009 & 5.89 & 25.01 & 7.54 \\
\hline 5 & 2010 & 5.16 & 23.19 & 7.63 \\
\hline 6 & 2011 & 6.68 & 18.75 & 7.71 \\
\hline 7 & 2012 & 4.44 & 17.33 & 7.91 \\
\hline 8 & 2013 & 4.15 & 17.51 & 7.68 \\
\hline 9 & 2014 & 4.18 & 17.44 & 7.29 \\
\hline
\end{tabular}

Sumber : BPS Provinsi Gorontalo, 2016

Dari tabel diatas, dapat dilihat tingkat pengangguran terbuka, tingkat kemiskinan dan pertumbuhan ekonomi Provinsi Gorontalo tahun 2006-2014 sebagaimana telah dijelaskan diatas. Selanjutnya untuk mengetahui bagaimana pengaruh pengangguran dan kemiskinan terhadap pertumbuhan ekonomi di Provinsi Gorontalo, akan dianalisis menggunakan regresi sederhana dan pengolahan data menggunakan program SPSS (Statistical Product Service Solution) Versi 21,0 untuk mempermudah perhitungan. Yang selanjutnya dianalisis dengan metode regresi dimaksud dari tabel diatas. 
Berdasarkan hasil olahan SPSS persamaan regresi dapat diketahui yaitu sebagaimana terlihat dalam lampiran hasil print out SPSS adalah : $\mathbf{Y}=\mathbf{7 . 9 8 9}$ $-0.008 \mathrm{X}_{1}-0.393 \mathrm{X}_{2}$

Koefisien determinasi yang disimbolkan dengan $R^{2}=(\mathrm{R}$ Square) adalah 0,159 dan Koefisien R adalah 0,399.

Tingkat signifikansi seluruh koefisien korelasi satu sisi yang diukur dari probabilitas menghasilkan angka 0,019. Karena probabilitasnya lebih kecil dari 0,05, maka korelasi antara variabel tingkat pengangguran dan tingkat kemiskinan (Variabel X1 dan X2) dan pertumbuhan ekonomi (Varibel Y) adalah signifikan. Selain itu terdapat beberapa hal yang perlu dijelaskan yakni tampak pada uraian sebagai berikut :

1. Desriptive Statistics dan Correlations.

- Rata - rata tingkat pengangguran terbuka adalah 5.6589 dengan standar deviasi 1.29329

- Rata - rata tingkat kemiskinan adalah 22.2878 dengan standar deviasi 4.62076

- Rata - rata pertumbuhan ekonomi adalah 7.5922 dengan standar deviasi 0.20566

- Tingkat signifikansi seluruh koefisien korelasi satu sisi yang diukur dari probabilitas menghasilkan angka 0,000. Karena probabilitasnya lebih kecil dari 0,05, maka korelasi antara variabel $\mathrm{X}_{1}, \mathrm{X}_{2}$ dan variabel $\mathrm{Y}$ adalah signifikan.

2. Variable Entered dan Model Summary

- Variabel yang dimasukkan adalah tingkat pengangguran terbuka dan tingkat kemisinan sebagai variabel $\mathrm{X}_{1}$ dan $\mathrm{X}_{2}$, dan tidak ada variabel yang dikeluarkan dari persamaan.

- Standard error of estimate adalah 394926956.89421 lebih kecil dari standard deviasi rata - rata pertumbuhan ekonomi (871042787.73111), artinya koefisien regresi lebih baik dijadikan sebagai prediktor pertumbuhan ekonomi dibanding dengan menggunakan metode mean atau rata - rata.

3. Anova dan Coeficients

- Dari uji Anova diperoleh F hitung 0.69 dengan tingkat signifikan 0,019. karena probabilitasnya lebih kecil dari $0,05(0,000<0,05)$, maka model regresi signifikan untuk memprediksi pertumbuhan ekonomi Provinsi Gorontalo, karena variabel bebas signifikan mempengaruhi variabel tak bebas.

- Persamaan regresi yang diperoleh adalah $\mathrm{Y}=7.989-0.008 \mathrm{X}_{1}-0.393 \mathrm{X}_{2}$ artinya apabila Tingkat Pengangguran Terbuka dan Tingkat Kemiskinan $\left(\mathrm{X}_{1}, \mathrm{X}_{2}\right)$ tidak ada atau $=0$ maka Pertumbuhan Ekonomi akan konstan pada tingkatan 7.989 dan $\mathrm{b} 1=-0,008$ artinya setiap adanya peningkatan variabel tingkat pengangguran terbuka, sebanyak 1 satuan akan menurunkan pertumbuhan ekonomi sebanyak 0,008 satuan dari semula dengan asumsi faktor lain konstan; b2 $=-0,393$ artinya setiap adanya peningkatan tingkat kemiskinan sebanyak 1 satuan akan menurunkan pertumbuhan ekonomi sebanyak 0,393 satuan dari semula dengan asumsi faktor lain konstan.

\subsection{Pembahasan}

Pada tahun 2006 jumlah pengangguran Gorontalo adalah sebesar 30.039 jiwa kemudian mengalami penuruan yaitu menjadi 27.973 jiwa tahun 
2007 dan 24.258 jiwa tahun 2008 kemudian naik lagi menjadi 26.351 jiwa tahun 2009 dan turun lagi mejadi 23.573 tahun 2010. Tahun 2011 pengangguran Gorontalo naik lagi dari tahun sebelumya yaitu sebesar 32.260 jiwa dan terakhir tahun 2014 berada pada angka 20.919 jiwa.

Tingkat pengangguran terbuka di Provinsi Gorontalo cukup berfluktuasi di Provinsi Gorontalo dari tahun 2006 sampai 2014, dimana pada tahun 2006 tingkat pengangguran terbuka Provinsi Gorotalo sebesar 7.62\% kemudian mengalami penurunan tahun 2007 dan 2008 yaitu $7.62 \%$ dan 5.65\%. Pada tahun 2009 naik lagi menjadi 5.89\% dan kembali turun pada tahun 2010 menjadi 5.16\% dan naik lagi tahun 2011 menjadi 6.68\%, dan kembali turun pada tahun 2012 yaitu 4.44\% ; dan tahun 2013 menjadi $4.15 \%$ selanjutnya pada tahun 2014 naik lagi menjadi 4.18\%.

Namun demikian angka ini masih dibawah angka tingkat pengangguran nasional, sehingga dapat dikatakan bahwa pengangguran masih berada pada kondisi yang tidak parah. Pertumbuhan ekonomi yang menunjukan kenaikan dari tahun ke tahun menyebabkan terbukanya kesempatan kerja baik disektor formal maupun informal di Provinsi Gorontalo.

Di Provinsi Gorontalo jumlah penduduk miskin dan tingkat kemiskinan berfluktuasi dari tahun 2006 sampai 2014. Dimana jumlah penduduk miskin Provinsi Gorontalo mengalami penurunan dari tahun 2006 hingga 2012, yaitu dari 273.90 ribu jiwa tahun 2006 berkurang menjadi 186.44 ribu jiwa tahun 2012, kemudian naik lagi menjadi 191.44 ribu jiwa tahun 2013 dan 194.10 ribu jiwa tahun 2014.

Adapun tingkat kemiskinan di Provinsi Gorontalo cukup berfluktuasi, dimana pada tahun 2006 tingkat kemiskinan Provinsi Gorotalo sebesar 29.13\% kemudian mengalami penurunan tahun 2007 dan 2008 yaitu $27.35 \%$ dan 24.88\%. Pada tahun 2009 naik lagi menjadi $25.01 \%$ dan kembali turun pada tahun 2010, 2011, dan 2012 yaitu $23.19 \%$; 18.75\% dan $17.33 \%$. naik lagi pada tahun 2013 menjadi $17.51 \%$ dan turun pada tahun 2014 menjadi $17.44 \%$.

Namun demikian secara umum terlihat bahwa angka kemiskinan di Provinsi Gorontalo ini berada jauh lebih tinggi dibandingkan angka kemiskinan nasional. Hal ini jelas mengingat penduduk miskin Gorontalo umumnya adalah penduduk yang bekerja di sektor pertanian, yang menyerap tenaga kerja paling banyak di Gorontalo. Baik Petani maupun Nelayan memiliki modal terbatas dan rata-rata mereka adalah tenaga kerja musiman. Di beberapa daerah pelosok Gorontalo, nelayan masih terjebak dengan praktek ijon sehingga memperparah kondisi pendapatan mereka, dan pada akhirnya akses terhadap pendidikan dan kesehatan mereka terbatas. Dari jumlah penduduk miskin Provinsi Gorontalo, terbanyak berada di Kabupaten Gorontalo dengan jumlah penduduk miskin terbesar yaitu 66.939 jiwa atau 18,87 \%. Sedangkan jumlah penduduk miskin terkecil berada di Kota Gorontalo yaitu 9.883 jiwa atau 5,49 $\%$.

Tingginya angka kemiskinan di Provinsi Gorontalo disebabkan oleh beberapa hal yaitu beberapa kabupaten yang ada di Provinsi Gorontalo merupakan daerah tertinggal dengan sumber daya alam (pertanian) yang terbatas sehingga sangat terbatas pula kemungkinannya untuk memaksimalkan potensi sumber daya. Penyebab lainnya adalah masih terbatasnya infrastruktur penunjang, seperti jalan, sekolah maupun prasarana ekonomi, utamanya bagi Papua Barat yang terletak di ujung timur Indonesia. Hal ini mengakibatkan keterbatasan akses bagi kelompok-kelompok miskin 
untuk memperbaiki kehidupannya, termasuk modal ekonomi yang dimiliki, baik lahan pertanian maupun keuangan. Selain hal diatas dari sisi sosial, penduduk miskin umumnya memiliki tingkat pendidikan yang relatif rendah mengingat terbatasnya kemampuan untuk mendapatkan akses pendidikan.Akibatnya, dalam kurun waktu singkat amatlah sulit untuk menurunkan tingkat kemiskinan tersebut.

Dari penjelasan diatas, maka terlihat jelas bahwa pengangguran dan kemiskinan berpengaruh terhadap pertumbuhan ekonomi di Provinsi Gorontalo. Hal ini juga sesuai dengan hasil perhitungan dengan menggunakan regresi sederhana, dimana tingkat signifikansi seluruh koefisien korelasi satu sisi yang diukur dari probabilitas menghasilkan angka 0,019. Karena probabilitasnya lebih kecil dari 0,05, maka korelasi antara variabel tingkat pengangguran dan tingkat kemiskinan (Variabel X1 dan X2) dan pertumbuhan ekonomi (Varibel Y) adalah signifikan.

Dilihat dari Koefisien $\mathrm{R}=0,399$ menunjukan secara simultan atau secara bersama-sama pengangguran dan kemiskinan berpengaruh positif terhadap pertumbuhan ekonomi meskipun pengaruhnya cukup kuat.

$\mathrm{R}$ Square atau Determinasi 0,159 menunjukan kontribusi variabel pengangguran terhadap kemiskinan terhadap pertumbuhan ekonomi Provinsi Gorontalo adalah sebesar $15,9 \%$ dan selebihnya adalah actor lain yang tidak dibahas dalam penelitian ini.

Adapun dilihat dari Koefiesien regresi parsial dimana nilai t (uji student) untuk variabel pengangguran dan kemiskinan masing - masing adalah pengangguran $=-0,014$ dengan tingkat signifikasi 0,041dan kemiskinan $=-$ 0,638 dengan tingkat signifikasi 0,027 menunjukan bahwa semua variabel independen memiliki hubungan yang signifikan pada taraf $a=0,05$ dengan variabel pertumbuhan ekonomi. Dari angka koefisien partial ini, kemiskinan menunjukkan angka yang paling dominan mempengaruhi variabel pertumbuhan ekonomi di Provinsi Gorontalo.

Berbasarkan hasil analisis di atas, maka hipotesis yang diajukan bahwa tingkat pengangguran dan kemiskinan berpengaruh terhadap pertumbuhan ekonomi di Provinsi Gorontalo, di terima.

\section{SIMPULAN DAN SARAN}

\subsection{Simpulan}

Berdasarkan uraian sebelumnya maka peneliti mengambil simpulan sebagai berikut :

1. Pertumbuhan ekonomi Provinsi Gorontalo berfluktuasi dari tahun 20062014, dan pertumbuhan paling tinggi terjadi pada tahun terakhir yaitu 2012 sebesar 7,91\% yang didorong oleh peningkatan aktifitas sektor pertanian dan jasa yang merupakan sektor penggerak roda perekonomian Gorontalo. Pada tahun 2009 terjadi penurunan pertumbuhan ekonomi dari tahun sebelumnya yaitu turun dari $7,76 \%$ menjadi $7,54 \%$. Hal ini sebagai imbas dari adanya krisis keuangan yang melanda hampir seluruh dunia membawa pengaruh bagi perekonomian Provinsi Gorontalo.

2.Tingkat pengangguran terbuka di Provinsi Gorontalo cukup berfluktuasi di Provinsi Gorontalo dari tahun 2006 sampai 2014. Namun demikian angka ini masih dibawah angka tingkat pengangguran nasional, sehingga dapat dikatakan bahwa pengangguran masih berada pada kondisi yang tidak parah. Pertumbuhan ekonomi yang menunjukan kenaikan dari tahun ke 
tahun menyebabkan terbukanya kesempatan kerja baik disektor formal maupun informal di Provinsi Gorontalo.

3. Tingkat kemiskinan di Provinsi Gorontalo cukup berfluktuasi, namun demikian secara umum terlihat bahwa angka kemiskinan di Provinsi Gorontalo ini berada jauh lebih tinggi dibandingkan angka kemiskinan nasional. Hal ini jelas mengingat penduduk miskin Gorontalo umumnya adalah penduduk yang bekerja di sektor pertanian, yang menyerap tenaga kerja paling banyak di Gorontalo. Baik Petani maupun Nelayan memiliki modal terbatas dan rata-rata mereka adalah tenaga kerja musiman.

4. Pengangguran dan kemiskinan berpengaruh terhadap pertumbuhan ekonomi di Provinsi Gorontalo. Hal ini juga sesuai dengan hasil perhitungan dengan menggunakan regresi sederhana, dimana tingkat signifikansi seluruh koefisien korelasi satu sisi yang diukur dari probabilitas menghasilkan angka 0,019. Karena probabilitasnya lebih kecil dari 0,05, maka korelasi antara variabel tingkat pengangguran dan tingkat kemiskinan (Variabel X1 dan X2) dan pertumbuhan ekonomi (Varibel Y) adalah signifikan.

\subsection{Saran}

1. Dalam rangka menanggulangi kemiskinan di Provinsi Gorontalo, sebaiknya pemerintah daerah membuat kebijakan penanggulangan kemiskinan yang lebih fokus pada upaya untuk meningkatkan pendapatan, kesehatan, dan pendidikan secara bersama-sama.

2. Sebaiknya pemerintah daerah Kabupaten Gorontalo mengevaluasi program bantuan kredit kepada masyarakat miskin yang sudah ada, dengan memperhatikan mekanisme dan administrasi yang mudah bagi mereka sehingga hal ini akan dapat membuka kesempatan kerja dan pada akhirnya menekan angka pengangguran

3.Membangun infrasturktur dasar dalam di Provinsi Gorontalo, seperti pemenuhan listrik dan jalan ke seluruh pelosok nantinya akan berdampak pada pertumbuhan ekonomi.

\section{REFERENSI}

Anonim, 2016. Produk Domestik Regional Bruto (PDRB) Menurut Lapangan Usaha. BPS Provinsi Gorontalo

Anonim, 2016. Profil Provinsi Gorontalo. BPS Provinsi Gorontalo Utara Arsyad, Lincolyn, 2010, Ekonomi Pembangunan, edisi Ke Lima, Bagian Penerbitan STIE YKPN : Yogyakarta.

Arsyad, Lincolyn, 2005, Pengantar Perencanaan Pembangunan Ekonomi Daerah, edisi Ke II, BPFE : Yogyakarta.

Badudu, J. S, Zein, Mohamad, 2001, Kamus Umum Bahasa Indonesia, Penerbit Pustaka Indah, Jakarta

Boediono, 1998, Ekonomi Mikro, Edisi Kedua, Cetakan Kedelapan, Penerbit BPFE Jogyakarta: Jogyakarta

Herlambang, Teddy, 2002, Ekonomi Makro, Penerbit Gramedia Pustaka Utama, Jakarta

Irawan, dan Suparmoko, 2011. Ekonomi Pembangunan. Edisi ke enam, Penerbit Graha Ilmu : Yogyakarta

Jhingan, ML. 2013. Ekonomi Pembangunan dan Perencanaan. Penerbit PT Raja Graindo ; Jakarta 
Jhingan, ML. 2012. Ekonomi Pembangunan dan Perencanaan. Cetakan Ke 14 Penerbit Mitra Wacana ; Jakarta

Mankiw, N.Gregory, 2010, Makro Ekonomi, Edisi Keenam, Penerbit Erlangga, Jakarta.

Murni, Asfia, 2009, Ekonomika Makro, PT Refika Aditama, Bandung.

Maulana, Achmad, 2004, Kamus Imiah Populer, Penerbit Absolut, Yokyakarta

Suparmoko, M dkk, 2000, Pokok-Pokok Ekonomika, Penerbit BPFE, Yokyakarta

Soekartawi, 2003, Teori Ekonomi Produksi Edisi Revisi, Penerbit PT Radja Grapindo Persada, Jakarta

Irawan \& Suparmoko, 2002, Ekonomika Pembangunan, edisi Ke II, BPFE : Yogyakarta

Kuncoro, Mudradjat, 2006, Ekonomi Pembangunan (Teori, Masalah, Dan kebijakan), edisi Ke empat, UPP STIM YKPN : Yogyakarta.

Kuncoro, Mudradjat, 2012, Perencanaan Daerah, Penerbit Salemba Empat : Jakarta.

Safii, 2008, Paradigma Baru Kebijakan Pembangunan Ekonomi Daerah, Averroes Press : Malang.

Sukirno, Sadono, 2004, Makro Ekonomi (Teori Pengantar), edisi Ke 15, PT Rajagrafindo : Jakarta.

Sukirno, Sadono, 1985, Ekonomi Pembangunan, LPFE UI : Jakarta.

Suparmoko. 2003, Ekonomi Publik Untuk Keuangan dan Pembangunan Daerah, penerbit Andi, Yogyakarta

Tarigan, Robinson. 2007, Ekonomi Regional, Teori dan aplikasi. Bumi Aksara : Jakarta

Todaro, M.P, 2000. Pembangunan Ekonomi di Dunia Ketiga, Penerbit Erlangga : Jakarta

Tambunan, Tulus. 2001. Perekonomian Indonesia, Teori dan Temuan Empiris. Ghalia ; Jakarta 